\title{
IMPLEMENTASI SANGGUL UKEL TEKUK SEBAGAI SANGGUL JAWA
}

\author{
Vony F.S Hartini Hipij \\ Email: vonnyhippy@yahoo.com \\ Sulistyami \\ Email: sulistyami@unipasby.ac.id \\ Fakultas Keguruan dan Ilmu Pendidikan Konsentrasi Tata Rias \\ Universitas PGRI Adi Buana Surabaya
}

\begin{abstract}
This research aims to see the results of ukel tekuk implementation. The design in this study using one shot case study with research subject of university student Adi Buana force of 2017 which amounted to 35 people. The research method used is a performance test to make buck ukel buckling. The conclusions of this study found that bun buckling uk is widely used by royal families, permasuri, princesses, host or caregiver and followed by the surrounding community.
\end{abstract}

Keywords: ukel tekuk style, one shot case study, performance test.

\section{PENDAHULUAN}

Indonesia merupakan negara yang kaya akan keanekaragaman suku dan budaya dari setiap daerah yang perlu dilestarikan demi masa depan bangsa sehingga pengetahuan anak-anak bangsa yang akan datang tidak memudar dan akhirnya menghilang.

Indonesia memiliki 33 sanggul yang telah dibakukan. Sanggul-sanggul tersebut mulai tersingkirkan seiring berkembangnya kebudayaan baik dalam maupun luar negeri. Sehingga pemahaman bagaimana cara membuat sanggul daerah berkurang dengan sendirinya.

Sanggul atau konde adalah rambut palsu maupun rambut asli yang dibentuk bulat atau oval dan ditempel pada bagian belakang maupun atas kepala. Sanggul sudah dikenal sejak jaman mesir kuno yang membuat sanggul dari rambut asli atau bulu hewan dan daun palma. Besar fungsi dan peranan rambut sebagai pelindung kepala dan hiasan kepala sehingga menambah keanggunan seseorang.

\section{KAJIAN TEORI}

Menurut Rostamalis, 2008 bahwa sanggul ukel tekuk merupakan salah satu sanggul yang diambil untuk mewakili banyaknya jenis sanggul di Indonesia. Bentuk-bentuk sanggul tersebut dapat diperoleh ilmunya dan dipelajari pada Lembaga Pendidikan non formal atau Lembaga kursus. Pada Lembaga Pendidikan non formal diberikan secara teori maupun praktek pengetahuan sehingga menguasai Teknik penataan dan pembuatan sanggul daerah terutama sanggul ukel tekuk.

Sanggul ukel tekuk merupakan sanggul yang digunakan oleh masyarakat dalam lingkungan keraton dengan ragam asesoris sebagai pembedanya. Peradaban sekarang, penggunaan sanggul ukel tekuk disesuaikan dengan perkembangan zaman, dalam arti tidak hanya dipakai oleh keluarga keraton saja, namun sudah dipakai oleh masyarakat diluar lingkungan keraton.

Penggunaan sanggul ukel tekuk disesuaikan dengan usia dan keperluan. Perbedaan ini terlihat dari kelengkapan perhiasan dan pakaian yang dikenakan. 
Berikut spesifikasi penggunaan sanggul ukel tekuk.

a) Putri remaja dengan usia 11-15 tahun (sesudah baliq) akan menggunakan sanggul ukel tekuk dengan haisan peniti ceplok ditengah dan peniti renteng di kanan dan kiri sanggul.

b) Putri dewasa akan menggunakan sanggul ukel tekuk dengan hiasan sama seperti putri remaja.

c) Inang atau pengasuh akan menggunakan sanggul ukel tekuk biasa tanpa hiasan.

Adapun cara membuat sanggul ukel tekuk adalah membagi rambut menjadi dua bagian mulai dari pangkal telinga bagian kanan ke pangkal telinga bagian kiri, ikat rambut bagian belakang telinga dan kusutkan rambut bagian depan telinga sehingga bias dibuat sunggar yang dirapikan menggunakan jepit bebek dan hair spray untuk menahan bentuk spy tidak rusak.

Pasangkan cemara pada ikatan rambut, putar cemara atau rambut ke arah kiri dan belok ke atas sampai pada ikatan rambut dan tahan dengan jepit supaya tidak lepas.

Sisa rambut atau cemara yang jatuh dibagian kanan disisir rapi dan kemudian ditekuk ke atas dan berhenti di bagian tengah ikatan rambut, kemudian balik rambut kea rah dalam, tekuk dan rapikan. Pasangkan hair net supaya bentuk sanggul tampak rapi.

Adapun cara membuat sunggar adalah sebagai berikut:

a) Rambut pada kedua sisi depan telinga disisir kearah atas dan tengah.

b) Kusutkan rambut dengan derajat pengangkatan 45 derajat.

c) Rapikan rambut sehingga membentuk kerucut pada bagian kanan dan kiri atas telinga. Selanjutnya memasangkan aksesoris.

d) Aksesoris secara umum digunakan adalah ceplok yang digunakan pada tengah sanggul bagian atas dan 2 jebehan yang menjuntai kebawah dan dipasangkan pada bagian kanan dan kiri sanggul.

Dari uraian diatas penggunaan sanggul menurut umur dan keperluan. Kaum wanita yang memakai sanggul sekarang menandakan bahwa ia telah lepas dari dunia remaja dan mulai menginjak masa kedewasaannya. Hal ini merupakan perlambangan bahwa gadis tersebut bagaikan bunga yang sedang mekar dan harum yang sanggup memikul tugas dan tanggung jawab dan siap berumah tangga.

\section{METODE PENELITIAN}

Penelitian ini merupakan penelitian ekseperimen dengan rancangan one shot case study yang menerapkan pembelajaran langsung melalui 3 kali pembelajaran. Adapun subjek penelitian adalah mahasiswa prodi PKK tata rias angkatan 2016 universitas PGRI adi buana Surabaya.

Data dikumpulkan melalui metode pengamatan, metode angket dan metode tes yang dianalisis menggunakan prosentase (\%).

\section{PEMBAHASAN}

Penelitian ini merupakan penelitian untuk pembelajarn bagi mahasiswa. Pembelajaran pertama mahasiswa diwajibkan membuat desain sanggul ukel tekuk diatas kertas. Kendala dalam pembelajaran tersebut yakni masih banyaknya mahasiswa yang kurang terampil dalam menggambar desain atau membuat desain sanggul ukel tekuk.

Pembelajaran kedua, mahasiswa mengamati demo pembuatan sanggul ukel tekuk yang dilakukan oleh dosen dengan suasana yang lebih tenang dan serius. Mahasiswa memperhatikan tahapan dalam membentuk sanggul dengan merekam atau memvideo langkah pembuatan sanggul dan selajutnya membuat sanggul tersebut pada boneka masing-masing.

Pembelajaran ketiga, mahasiswa membuat sanggul ukel tekuk pada model, disini pembentukan dilakukan secara bergantian atau antar teman. Berikut hasil pembelajaran hari pertama, kedua, dan ketiga yang disajikan dalam bentuk Tabel 1 
Tabel 1. Praktik Pembelajaran oleh Mahasiswa

\begin{tabular}{|c|c|c|c|c|}
\hline No & Nama Siswa & $\mathrm{H} 1$ & $\mathrm{H} 2$ & $\mathrm{H} 3$ \\
\hline 1. & Aci Savita & 75 & 87 & 90 \\
\hline 2. & Aprilia Aaries Tanti & 70 & 80 & 89 \\
\hline 3. & Dana Iswara & 75 & 85 & 85 \\
\hline 4. & Devi Duwita Purindah & 85 & 80 & 85 \\
\hline 5. & Devi Irma Cahyani & 75 & 79 & 85 \\
\hline 6. & Dinda Afria & 85 & 80 & 85 \\
\hline 7. & Dwi Ainun Fitria & 75 & 85 & 89 \\
\hline 8. & Dwi Pertiwi Oktafia & 80 & 80 & 80 \\
\hline 9. & Efi Rahmawati & 81 & 80 & 85 \\
\hline 10. & Eka Dian Pertiwi & 75 & 85 & 91 \\
\hline 11. & Evi Susanti & 85 & 85 & 85 \\
\hline 12. & Fine Erliana & 75 & 85 & 89 \\
\hline 13. & Fitria Ainun Zilvi & 70 & 70 & 70 \\
\hline 14. & Iga Mey Margasari & 75 & 79 & 85 \\
\hline 15. & Lailatul Chotimah & 85 & 80 & 85 \\
\hline 16. & Lina Dwi Arini & 75 & 85 & 91 \\
\hline 17. & Novia Savitri & 80 & 84 & 85 \\
\hline 18. & Nurul Kharisma & 75 & 85 & 89 \\
\hline 19. & Oktavia Dwiningsih & 85 & 85 & 85 \\
\hline 20. & Riska Ridho Febrianti & 81 & 80 & 85 \\
\hline 21. & Restu Indra Lestari & 85 & 80 & 85 \\
\hline 22. & Setiyo Windi Meita Sari & 75 & 85 & 89 \\
\hline 23. & Sulastri Puji Astutik & 85 & 75 & 75 \\
\hline 24. & Susianti & 80 & 75 & 80 \\
\hline 25. & Yanti Pertiwi & 90 & 85 & 89 \\
\hline 26. & Nanda Pratiwi & 75 & 85 & 80 \\
\hline 27. & Rina Yuliani & 80 & 85 & 90 \\
\hline 28. & Moch Munir & 75 & 80 & 85 \\
\hline 29. & Moch Kamim & 80 & 80 & 90 \\
\hline 30. & Dinda Kanaya & 75 & 75 & 85 \\
\hline 31. & Elfira Kusumawati & 80 & 80 & 85 \\
\hline 32. & Teresia Pardede & 75 & 80 & 85 \\
\hline 33. & Kriswanda Ferdy & 80 & 75 & 85 \\
\hline 34. & Irmawati Ismail & 75 & 85 & 80 \\
\hline 35. & Marini & 75 & 85 & 80 \\
\hline
\end{tabular}

Dari Tabel 1 diperoleh rata-rata untuk pembelajaran pertama mahasiswa membuat desain sanggul ukel tekuk diatas kertas diperoleh nilai rata-rata 78,5 \% dengan kendala masih banyaknya mahasiswa yang kurang terampil dalam menggambar desain atau membuat desain sanggul ukel tekuk.

Pembelajaran

kedua, mahasiswa membuat sanggul pada boneka dan diperoleh rata-rata sebesar
$78,8 \%$ dengan kendala bahwa rambut boneka lebih susah diatur dari pada rambut model atau rambut asli.

Pembelajaran

ketiga, mahasiswa membuat sanggul ukel tekuk secara bergantian atau antar teman yang diperoleh skor sebesar 84,9\% dengan kendala rambut model rata-rata lebih licin sehingga susah untuk dikusutkan.

\section{KESIMPULAN}


Sanggul ukel tekuk merupakan sanggul tradisional dari pulau jawa. Implementasi sanggul ukel tekuk mampu dilakukan dengan baik oleh mahasiswa sebagai generasi muda dan penerus bangsa. Upaya pelestarian sanggul ukel tekuk adalah dengan mewajibkan siswa menggunakan sanggul ukel tekuk pada acara hari kebesaran nasional (hari kartini, acara besar wisuda, dll), memajang bentuk sanggul pada museum daerah, mengadakan acara show terkait dengan sanggul ukel tekuk dan busana daerah yang sesuai dengan sanggul tersebut.

\section{DAFTAR PUSTAKA}

http://langkir1st.blogspot.com/konseppenataan-rambut.html diakses 1 Juni 2012

Kusumadewi,dkk. 1999.

Pengetahuan dan Seni Tata Rambut Modern. Jakarta: PT.Carina Indah
Puspoyo, Widjanarko, Endang. 2006. Sanggul. Jakarta: Gramedia Pustaka Utama

Rostamialis. 2008. Tata Kecantikan Rambut.Jakarta:Direktorat Pembinaan Sekolah Menengah Kejuruan,Direktorat Jenderal Manajemen Pendidikan Dasar dan Menengah

https://www.slideshare.net/neollapride2 4/sanggul-ukel-tekuk-diy. Diakses tanggal 29 Januari 2018 jam 11.03

https://periaspanggilanyogyakartaprofesi onal.wordpress.com/tag/sanggulukel-tekuk-daerah-istimewayogyakarta/. Diakses tanggal 29 Januari 2018 jam 11.09

http://ukeltekuk.blogspot.co.id/. Diakses tanggal 29 Januari 2018 jam 11.13

https://dokumen.tips/education/sanggulukel-konde-dari-solo-jawatengah.html. Diakses tanggal 29 Januari 2018 jam 11.24

Santoso, Tien. 1999. Sejarah Penganten Daerah Indonesia (Diktat).Universitas Negeri Jakarta. 